\title{
III. GRAIN-SIZE ANALYSES, LEG 33
}

\author{
Gerald W. Bode, Scripps Institution of Oceanography, La Jolla, California
}

Sand-silt-clay distribution was determined on 10-cc sediment samples collected at the time the cores were split and described. The results are listed in Table 1.

The sediment classification used here is that of Shepard (1954) with the sand, silt, and clay boundaries based on the Wentworth (1922) scale (Figure 1). Thus the sand, silt, and clay fractions are composed of particles whose diameters range from 2000 to $62.5 \mu, 62.5$ to $3.91 \mu$, and less than $3.91 \mu$, respectively. This classification is applied regardless of sediment type and origin; therefore, the sediment names used in this table may differ from those used elsewhere in this volume, e.g., a silt composed of nannofossils in this table may be called a nanno ooze in a site chapter.

Standard sieve and pipette methods were used to determine the grain-size distribution. The sediment sample was dried and dispersed in a Calgon solution. If a sediment sample failed to disaggregate, it was treated with a sonic probe and, if necessary, hydrogen peroxide. Sediment samples which resisted the above treatment were not analyzed.

The sand fraction was removed by wet sieving using a $63 \mu$ sieve, and the silt and clay fractions were analyzed by standard pipette analysis. Sampling depths and times were calculated using equations derived from Stokes settling velocity equation (Krumbein and Pettijohn, 1938, p. 95-96):

$$
\begin{aligned}
& D=V=\frac{2\left(d_{1}-d_{2}\right) g r^{2}}{9 \eta} \\
& t=\frac{9 D \eta}{2 g r^{2}\left(d_{1}-d_{2}\right)}
\end{aligned}
$$

where

$V=$ velocity, in $\mathrm{cm} / \mathrm{sec}$

$t^{1}=$ time, in sec$^{*}$

$D=$ depth pipette is inserted, in $\mathrm{cm}$

$g^{1}=$ gravity, in $\mathrm{cm} / \mathrm{sec}^{2 *}$

$r^{1}=$ radius of individual particles, in $\mathrm{cm}^{*}$

$d_{1}=$ density of solid particles arbitrarily set at 2.675 $\mathrm{g} / \mathrm{cc}$

$d_{2}=$ absolute density of distilled water at different temperatures (Hodgman et al., 1960, p. 2129)

$\eta^{1}=$ viscosity of distilled water in poises at different temperatures (Hodgman et al., 1960, p. 2181)

*Five figures were used in calculations to avoid rounding off variations.
TABLE 1

Grain-Size Determination for DSDP Leg 33

\begin{tabular}{lccccc}
\hline $\begin{array}{c}\text { Core-Section, } \\
\text { Top of Interval } \\
(\mathrm{cm})\end{array}$ & $\begin{array}{c}\text { Depth } \\
(\mathrm{m})\end{array}$ & $\begin{array}{c}\text { Sand } \\
(\%)\end{array}$ & $\begin{array}{c}\text { Silt } \\
(\%)\end{array}$ & $\begin{array}{c}\text { Clay } \\
(\%)\end{array}$ & Classification \\
\hline Hole 315 & & & & & \\
$1-1,122$ & 1.22 & 4.3 & 20.6 & 75.1 & Clay \\
$1-2,24$ & 1.74 & 3.4 & 33.5 & 63.1 & Silty clay \\
$1-2,82$ & 2.32 & 6.3 & 26.5 & 67.2 & Silty clay \\
$1-3,81$ & 3.81 & 4.3 & 22.6 & 73.1 & Silty clay \\
$1-4,46$ & 4.96 & 3.3 & 26.2 & 70.5 & Silty clay \\
$1-5,23$ & 6.23 & 6.9 & 26.9 & 66.2 & Silty clay \\
$1-6,137$ & 8.87 & 5.3 & 21.9 & 72.8 & Silty clay \\
$4-2,118$ & 59.18 & 4.9 & 29.4 & 65.7 & Silty clay \\
$4-3,60$ & 60.10 & 4.5 & 29.9 & 65.6 & Silty clay \\
$4-3,92$ & 60.42 & 6.7 & 32.1 & 61.2 & Silty clay \\
4, CC & 65.60 & 4.3 & 29.3 & 66.4 & Silty clay
\end{tabular}

Hole 315A

$\begin{array}{llllll}5-1,12 & 370.12 & 28.6 & 32.6 & 38.8 & \text { Sand-silt-clay }\end{array}$

Site 318

\begin{tabular}{lrrrrl}
$1-3,0$ & 3.00 & 75.1 & 16.9 & 8.1 & Sand \\
$1-3,21$ & 3.21 & 79.7 & 12.9 & 7.4 & Sand \\
$7-4,3$ & 183.53 & 29.8 & 55.9 & 14.4 & Sandy silt \\
$7-4,78$ & 184.28 & 66.0 & 23.2 & 10.8 & Silty sand \\
$7-4,103$ & 184.53 & 69.3 & 19.6 & 11.0 & Silty sand \\
\hline
\end{tabular}

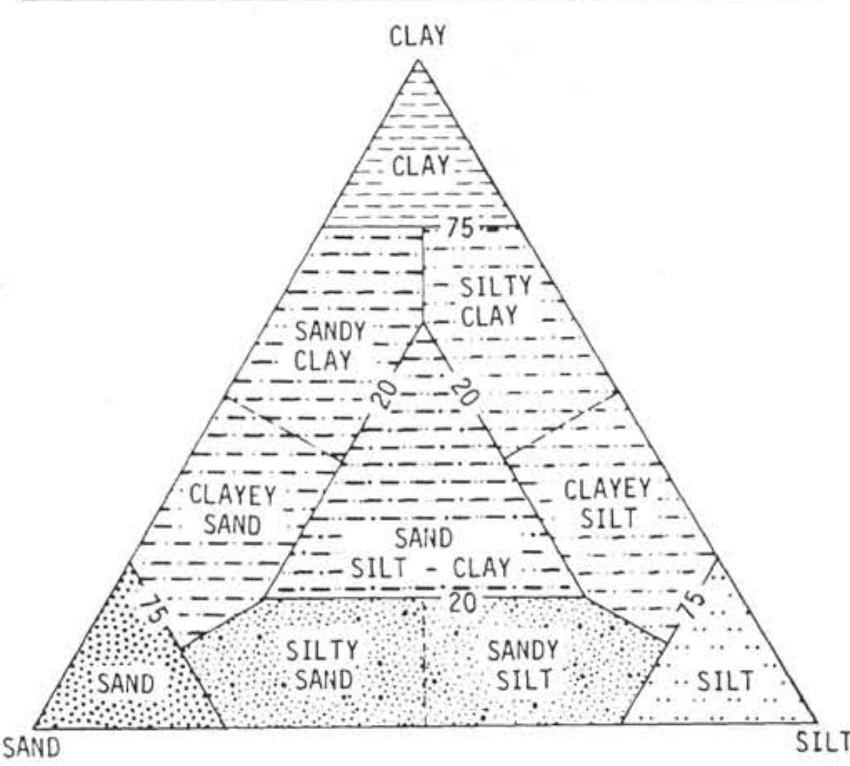

Figure 1. Sediment classification after Shepard (1954) with the sand, silt, and clay size fractions based on the Wentworth (1932) Grade Scale: Sand, silt, and clay size particles having respective diameters of 2000 to $62.5 \mu, 62.5$ to $3.91 \mu$, and less than $3.91 \mu$. Shepard's (1954) sediment classification is a function of sand, silt, and clay size percentages and not composition. 
The reproducibility of the grain size analysis has been previously tested (Boyce, 1972), and it was found that over a period of time with several operators the reproducibility for the sand-silt-clay fractions is $\pm 2.5 \%$ (absolute). For detailed step-by-step procedures, see Volume 4 of the Initial Reports of the Deep Sea Drilling Project.

\section{REFERENCES}

Boyce, R.E., 1972. Grain size analyses, Leg 9, Deep Sea Drilling Project. In Hayes, J.D., Initial Reports of the Deep Sea
Drilling Project, Volume 9: Washington (U.S. Government Printing Office), p. 779.

Hodgman, C.D., Weast, R.C.Y., and Selby, S.M., 1960. Handbook of chemistry and physics: Cleveland (Chemical Rubber Publishing Co.).

Krumbein, W.C. and Pettijohn, F.J., 1938. Manual of sedimentary petrography: New York (Appleton-CenturyCrofts, Inc.).

Shepard, F.P., 1954. Nomenclature based on sand-silt-clay ratios: J. Sediment. Petrol., v. 24, p. 151.

Wentworth, C.K., 1922. A scale of grade and class terms for clastic sediments: J. Geol., v. 30, p. 377. 